\title{
"Seeking a Widow with Orphaned Children': Understanding Sutra Marriage Amongst Syrian Refugee Women in Egypt
}

\author{
Dina Taha
}

Egypt currently hosts more than 200 thousand refugees registered by the UNHCR all living in urban communities. More than half, around 120 thousand are from Syria ${ }^{1}$ (ECHO Factsheet: Egypt, 2018) arriving after 2011. Fleeing one of the worst humanitarian crises since World War II, Syrians arrive to an economically troubled country and a politically polarizing atmosphere, where they face a lack of opportunities and a high cost of living. Some Syrian women in Egypt have drawn the attention of media, religious leaders, and advocacy groups by marrying Egyptian men soon after arriving (Hassan 2015; Geha 2013). Social media campaigns such as Laajiat Lasabaya (Lājiāt la Sabāyāa ${ }^{2}$ or "Refugees, not spoils of war" (also rendered on their Facebook page as: Refugees...Not Spoils) were ignited as a reaction to this practice in Egypt, as well as Lebanon, Jordan and other Arab countries where such marriages have been facilitated, encouraged and organized through different channels such as marriage brokers, social media and religious organizations (Barkan 2012).

This paper is part of a broader study that I conducted for my fieldwork in Egypt during the summer of 2017 where I interviewed thirty-three Syrian refugee women who escaped the conflict in Syria and married Egyptian men post 2011 once they settled in Egypt. It highlights a recurring notion that I came across during many of the interviews_Zawāj al-Sutra (Protection or Shelter Marriage). In such cases, the man is motivated to marry a widow, especially that of another man who died because of war, with the intention of providing her and her children with livelihood and emotional support. Such a practice

1 The rest are mostly from east Africa or Iraq (ECHO Factsheet: Egypt, 2018). These figures don't include Palestinian refugees (see for instance: Palestine refugees: locations and numbers, IRIN, 2010).

2 More information about the campaign available at: <https://www.facebook.com/Lajiaat. Lasabayaa >. 
was arguably recurrent throughout Islamic history where many have suggested it was encouraged in the Islamic tradition.

Muslim scholars' increased interest in the ways Shari' $a$ cultivates ethics and virtue beyond the legally binding provisions in the modern era is arguably novel, compared to pre-modern scholars (Katz 2015, 26). Some factors can be traced back to the impact of modernity and its repercussions on the emergence of a modern (human) subject, as well as the formation of the nationstate and codified law, particularly personal status law, in many Muslim majority countries on the relationship between Islamic jurisprudence and Islamic ethics (ibid., 25). This interest in incorporating ethical questioning due to modern dictates, as argued by Tariq Ramadan, [should] change the foundation and nature of Islamic legal reasoning, requiring a more holistic approach and an understanding of the theory of knowledge "that generates meaning and the ethical questions generated by social, scientific, and intellectual development" (Ramadan 2017,15 ). Thus, formulating legal rulings to govern forced migration, a phenomenon that emerged at the end of the second world war and the prevalence of the nation-state as the dominant form of political governance, requires sufficient mastery over the field of knowledge that religious rulings are based upon, including an understanding of the higher ethical objectives of Shari'a (Maqāṣid).

I approach the phenomenon of Sutra marriage from an anti-colonial theoretical framework which seeks to analyze and use local cultures as a tool to resist "the everyday devaluation, denial and negation of the creativity, agency, resourcefulness and knowledge systems" of non-Western cultures (Dei 2012). Among the pioneers of Postcolonial Feminism, Gayatri Chakravorty Spivak and Chandra Talpade Mohanty in particular have (re)developed the theories of Frantz Fanon and Edward Said towards the creation of Postcolonial/Antiorientalist critical approaches of knowledge production to challenge Western hegemonic ways of knowing. Mohanty asserts that portrayals of Third World women as victims contribute to further marginalizing those women (Mohanty 1984). Anti-colonial frameworks, however, do not attempt to deny the existence of victimhood and victimizing dynamics in the Global South; rather, they seek to challenge essentialized understandings of binaries such as victims or agents.

My objective from offering an anti-colonial reading of this case study is twofold: first, by shedding more light on the complexity of the woman refugeeness through addressing women's multidimensional and complex forms of oppression and autonomy in the Global South, I aim to offer Islamic scholars and jurists a critical language that responds to the often-orientalised feminist and human rights advocates' characterizations of gendered relations 
in non-Western contexts. Second, an anti-colonial feminist perspective showcases the need for having a "gendered" approach to Islamic fatwas. A gendered approach can be traced whether in offering a "meaningful and healing" solution to refugee women, and Muslim women in general, or in revisiting and assessing the complex power dynamics that defines conjugal relationships of the kind being addressed here.

Moreover, in response to the changing nature of global mobility and in commitment to the anti-colonial principle that seeks to destabilize Eurocentric hegemonic ways of knowing, the article also seeks to pose questions that push the debates surrounding the ethics of migration today. Particularly, Can Sutra marriage be considered an ethical and moral response to the gendered forced migration? Can it be regulated to echo calls for gender equality and gender empowerment? Who sets the rules about principles and notions of international humanitarianism? How can we include cultural diversity, including gender, ethnicity, and sexual orientation in ethics of migration? And whose voices should be included in these discussions?

Hence, this is not an ethical, legal, or jurisprudential paper per se, but offers important sociological insights to jurists in issuing fatwas that are better informed about contemporary realities, gender discourses and forced migrants' experiences. Sociology "as the study of the individual, society and the relationship between structures and group processes" (Castles 2002) should assist jurists, particularly with regard to understanding human mobility, in grasping the societal dynamics of forced migration. A particular contribution relevant to this study is introducing issues around identity (re)formation and the effect forced migration might have on traditional gender roles in the modern (and post-modern) world order as well as critiquing notions such as victimhood and exploitation from both gender and forced migration perspectives.

I start by positioning this practice in Islamic jurisprudence and the role played by the jurisprudential culture in defining Sutra marriage and its parameters. I then critically engage with a sample of contemporary fatwas in order to trace the jurisprudential perception to Sutra as grounds for marriage and Sutra marriage as a tool for shelter and aid to Muslim (women) refugees. Next, I relate the stories of three women to unfold the different trajectories and the mixed experiences that Sutra marriage has taken with different Syrian refugee women in Egypt. I seek to address these marriages from the women's perspective in a way that goes beyond assessing them morally, but to expose the gaps between the fatwa's opinion, vision and advice and the application, especially given the vulnerable status of many forced migrants. Finally, and using an anticolonial lens, I conclude with a discussion of (a) how the narratives discussed pose theoretical and conceptual challenges to some central feminist concepts 
such agency and gender roles, and (b) some avenues through which sociological research can offer Islamic jurisprudence a deeper understanding of the experiences, and consequently the needs of some marginalized groups such as refugee women in Muslim societies.

\section{Sutra Marriage in the Islamic Jurisprudential Texts and Cultures}

The term "Zawāj al-Sutra" has been used by both media and advocacy groups to mean different things, including marrying rape victims (Barkan 2012; Natour 2016). In the fatwas below, three meanings of Sutra marriage emerge. First, Sutra in the general sense means providing Iffa or chastity and modesty. In that sense, marriage is considered as a means for the gratification of sexual needs and procreation (Mir-Hossein 2003). Second, Sutra can be perceived as a means for providing relief for rape victims (or women who committed adultery and then repented). Third, Sutra can be used in the sense of providing shelter, livelihood support and protection for widows and divorced women. ${ }^{3}$ The last meaning is the primary concern of this paper.

Keeping the above in mind, I turn to examining four fatwas that I was able to authenticate from the Fatwa Center website. The Fatwa Center is a scientific Islamic portal affiliated with the Ministry of Awqā and Islamic Affairs in Qatar. It is concerned with answering questions related to the Muslim faith, worship, transactions, ethics, behavior, and other matters. ${ }^{4}$ The small sample size of the selected fatwas goes back to the rigorous verification process. During this verification process I was committed to the following criteria: (1) excluding any fatwas that did not mention the name and the credentials of the Mufti (jurist) or the body of jurists responsible for issuing the fatwa; (2) excluding any fatwas mentioned on social media or blogposts due to the overrepresentation of fabricated fatwas, fake news, unauthenticated post-sharing about Islamic scholars issuing controversial fatwas surrounding Syrian refugee women in particular; 5 (3) excluding fatwas that were acquired orally, no matter how prevalent they

3 In the nineties, the notion of Sutra marriage started to gain cultural association with Muslim war victims and refugee women. It began with Bosnian women in the late gos followed by Iraqis and recently Syrians.

4 More information about the fatwa center available at: <http://fatwa.islamweb.net/fatwa/ index.php?page=aboutfatwa $>$.

5 For instance, a fake news was disseminated among different media portals that the Saudi Scholar Muhammad al-'Arifî issued a controversial fatwa allowing what they referred to as Jihād al-Nikāh. More information available here: <https://www.youtube.com/watch?v= JLiNl7MyWPk>. 
were. The latter contained fatwas acquired through personally asking a scholar or those propagated during Friday sermons. This criterion also excluded fatwas mentioned by some of my respondents during the interviews.

Most references relied on two avenues to justify and encourage Sutra marriage for widows and divorced women. The first is by citing historical incidents where the prophet himself or his companions were eager to marry widows and divorced women (see for instance, AlHamoud, 2011). A second avenue was through citing religious texts from Quran and Sunnah that encourage Muslims to protect each other, especially the most vulnerable like the poor, widows and orphans ${ }^{6}$ and emphasize the reward for taking care of them. For instance, it is reported on the authority of Abū Hurayra that the Prophet said: "Whoever removes a worldly grief from a believer, Allah will remove from him one of the griefs of the Day of Resurrection. And whoever alleviates the need of a needy person, Allah will alleviate his needs in this world and the Hereafter. Whoever shields [or hides the misdeeds of] a Muslim, Allah will shield him in this world and the Hereafter. And Allah will aid His slave so long as he aids his brother..." [al-Nawawī 40 Hadith, no. 36]. In another report, the Prophet said, "One who cares for widows and the poor is like those who fight in the way of Allah or those who spend their days fasting and their nights praying." [al-Bukhārī Adab al-Mufrad, chapter "The Virtue of Those Who Care for Orphans"-Agreed upon hadīth]. A third report states that Umm Sa'īd bint Murra al-Fihrī related from her father that the Prophet, may Allah bless him and grant him peace, said, "I and the guardian of an orphan will be in the Garden like these two (His two fingers)." [al-Bukhārī Adab al-Mufrad, chapter "The Virtue of Those Who Care for Orphans"]

In all the four fatwas below, the notions of Sutra (covering, protection or sheltering) and Iffa (chastity and modesty) were referenced explicitly or implicitly as "noble" grounds and a reason for marriage. The fatwas address cases involving widows, refugee women, or other vulnerable cases such as rape victims and women who lost their virginity due to unlawful intercourse. Following is a brief summary of each fatwa.

\subsection{Fatwa (1): Marrying with the Intention of Providing Chastity}

In this fatwa, the inquirer is referring to some Facebook pages that facilitate the marriage of Syrian women living in Egypt. He expressed his wish to provide

6 In Islamic fiqh, an orphan is someone who has lost their father or both parents before the age of maturity.

7 The script of the fatwa was taken from: <http://fatwa.islamweb.net/fatwa/index.php?page=s howfatwa\&Option=FatwaId\&Id=235441> (last accessed May 2018). 
chastity (Iffa) to a Syrian sister and asked whether this wish and intention are permissible and if the muftì (jurist) has any advice for him. The fatwa responds by confirming the permissibility of marrying a Syrian Muslim woman. In fact, it encouraged the inquirer to do so because the intention of providing her with chastity as well as emotional support in her hardship is an act that will be rewarded generously.

\subsection{Fatwa (2): Marrying a Widow with Orphans $^{8}$}

In this fatwa, the inquirer seeks guidance for his intention to marry a widow as a second wife but planning to keep it a secret from his first wife. He explained that he sought this marriage in order to take care of her orphaned children but then changed his mind last minute after realizing that his intentions weren't "pure." He came to the conclusion that he can support the orphans without the marriage or the secrecy. The fatwa responded by describing sheltering a widow and her orphans through marriage as a good deed that would be rewarded. It encouraged him to be honest with his first wife but clarified nevertheless that he is not obliged religiously to inform her.

\subsection{Fatwa (3): Marrying to Cover a $\operatorname{Sin}^{9}$}

In this fatwa, a woman was asking about the legal and religious obligation on a man she was in a relationship with and with whom she lost her virginity. She mentioned that he has always expressed his loyalty to her and his desire to eventually marry her, but his family ended up opposing the marriage. The woman is asking the mufti to encourage the man to take responsibility for his actions. The fatwa started by condemning both the man and the woman for their behaviour and asserted that even though the man is not religiously obliged to do so, he "should" marry her with the intention of applying Sutra to her and he would be rewarded for his deed. The fatwa quotes the hadith "Whoever shields [or hides the misdeeds of] a Muslim, Allah will shield him in this world and the Hereafter..."

\subsection{Fatwa (4): Marrying a rape victim ${ }^{10}$}

In this fatwa, the man states that after proposing to a girl, she asked to meet him privately and confessed that she was raped at 17 and that she hasn't told

8 The script of the fatwa was taken from: $<$ http://fatwa.islamweb.net/fatwa/index.php?pag $\mathrm{e}=$ showfatwa \&Option=FatwaId\&Id=66438 $>$ (last accessed May 2018).

9 The script of the fatwa was taken from: $<$ http://fatwa.islamweb.net/fatwa/index.php?pag $\mathrm{e}=$ showfatwa \&Option=FatwaId\&Id=63748 $>$ (last accessed May 2018).

10 The script of the fatwa was taken from: $<$ http://fatwa.islamweb.net/fatwa/index.php?pag $\mathrm{e}=$ showfatwa $\&$ Option=FatwaId $\& I d=7994>$ (last accessed May 2018). 
anyone including her parents. He is asking for a religious opinion whether to marry her. The fatwa responds that, under the condition that he can trust that she is telling the truth, he should pray Istikhära (the prayer of seeking guidance from Allah) and weigh in her religious devotion before he moves on with the marriage. The muftī stresses that there is no objection in marrying her especially that what happened to her was beyond her control. The fatwa also encouraged him, whether he decided to marry her or not, not to disclose her secret to anyone and also cites the hadith "Whoever shields [or hides the misdeeds of] a Muslim, Allah will shield him in this world and the Hereafter..."

From the above fatwas, one can notice that they are motivated to a large extent by the mufti's assessment of advancing the women's interest. Each fatwa encouraged an action based on the assumption that it will provide emotional support to the woman during hardship, when it encouraged the inquirer to be honest with his first wife, even though he is not obliged to, or when it advised the inquirer not to disclose the rape victim's secret. On the other hand, recalling the relationship between Islamic jurisprudence and advancing virtue and ethics, there were also common issues between the fatwas and their understanding of the woman's best interest, which create dilemmas for the contemporary understanding and application of social justice, especially for vulnerable groups such as uprooted refugees. First, the fatwas place a huge weight in their rationale and verdict on the "pure" intention of the man without identifying accountability measures to protect the women from future potential abuse. Second, they frame the marriage decision-making, or lack thereof, almost solely in the hands of the man and his discretion. Third, and most importantly, they portray the woman as a one-dimensional character lacking any depth or any form of varied experiences, agency or preferences. That is to say, the fatwas do not pay diligent attention to the individual women's circumstances. For them, a rape-victim and the widow, a woman who lost her virginity and a refugee, all have the same needs and are the same woman - "the" woman. This woman is often portrayed as the victim who needs to be saved (by "the" man).

In the following section, I try to add a "face" to "that woman" in the above fatwas while focusing on the experience of the refugee woman. In doing so I demonstrate that different women have different approaches and understanding of Sutra marriage; and in many occasions, defy the "victim" image that underlies the rationale and the verdict of many jurisprudential texts that address marriage and spousal rights. 
Three women that I came across during my fieldwork: Maha, Marwa and Nour ${ }^{11}$ presented three interesting and variant trajectories to what they themselves labelled as Sutra marriage. The three women are Syrian refugees who arrived in Egypt after 2012 and settled in the city of 'Āshir min Ramaḍān (or of Al-'Áshir for short), a newly industrial but suburban city in Sharqiyya governorate and is considered to be part of greater Cairo. The three women had children from previous marriages and they all referred during their interviews to Sutra or Sutra marriage. Marwa and Nour are siblings and they are in close acquaintance with Maha. Despite all the commonalities, their stories present three different understandings and outcomes to their marriage experiences.

\section{$4 \quad$ Maha: Killing Two Birds with One Stone}

Maha was in her 40s. She grew up in Damascus (commonly referred to as Shām) in a well-off area. Unlike many of the Syrian women that I have interviewed, she went to law school where she met her first husband and got married after a "powerful" love story. When she got divorced, she refused to marry for 11 years because most suitors requested that her children stay behind with her family, which she firmly refused. After arriving to Egypt in December 2012 and settling within the relatively large Syrian community in the city of $\mathrm{Al}$ 'Asshir, like many of her counterparts, marriage proposals started to pour in. When I asked her if she was seriously considering marriage to an Egyptian and her motivation behind this marriage, her response was mainly focused on emotional and social support that results from having a male figure in one's life in an Arab country.

D: But you weren't opposed to the idea of marriage?

M: No, because the situation was really tough to be honest. After my siblings left (to Saudi Arabia) and my parents are old and all my siblings are married, I thought that I have to get married.

D: And how did you generate income (before marriage)?

M: My parents

D: Oh, so you didn't need marriage for financial reasons but socially and emotionally. 
M: I am very romantic, and there was a love story with my first husband, so it was a tough situation because 10 years... it is like they say "emotional drought" .... God bless my children.

D: So, when you got married you didn't feel obliged to?

M: I had to get married. Like they say marriage is Sutra.

D: What do you mean marriage is Sutra?

M: I found that without (marriage) many men crossed the line with me. It is protection and support for me later on. And my kids too need a father.

Of course, I was intrigued by the concept of Sutra so I asked her to expand a little bit on her interpretation of its meaning and how she would explain the Egyptian men's eagerness to marry Syrian women. Her response reflects not just a conscious understanding of the realities and driving forces of this notion but also a sense of control of the situation. That is, in this kind of marriage, she is also offering something in return not merely waiting to be saved or protected.

D: ... you mentioned that many (Egyptian men) wanted to marry you. Did you ask them why?

M: They say they want to apply Sutra to my children. They don't say it explicitly, but we get it.

D: So what do they say?

M: They don't say that "exactly." Of course, they appreciate our tidiness, cleanliness, and beauty. But in some cases, they say it explicitly, like in Marwa's case: so that he would protect her (apply Sutra) and her children and receive reward (religious oblation). Of course, it's not just for that (the oblation) but it's also for himself. It's like killing two birds with one stone. On the one hand, he would receive a huge reward that he raised her kids and on the other, she is Syrian. She is going to make him happy and pleased. That's the opinion of all of them (the Egyptian men) because they have witnessed similar experiences before their eyes and they have noticed our different nature (compared to Egyptian women). For example, with my husband, his friends would tell me: you switched him 180 degrees. Even his kids...

Overall, Maha's marriage seemed to be a positive experience. Despite being a second wife and going through a few hiccups due to the first wife's resistance, she expressed on multiple occasions that she carries respect to her current husband, that she has fallen in love with him and that she was trying hard to get pregnant for the second time with him. In fact, when asked explicitly about 
her marriage experience in Egypt compared to that back home in Syria, she enthusiastically concluded that she is better off with her Egyptian husband and that in general Egyptian husbands are better than Syrian ones largely due to cultural and social habits.

\section{5}

\section{Nour: "Tasting a New Fruit in the Market"}

Nour was the youngest. She was 25 years old when her husband got killed in Damascus a year and a half before our interview. She and her daughter were, hence, forced to catch up with her family in Egypt a few months later after illtreatment at her in-laws' household. Just a few months after arrival, a family friend introduced them to an Egyptian man who is married with kids but was searching for a Syrian widow to apply Sutra to. They had the religious marriage ${ }^{12}$ three weeks after they first met. She noticed a change in her new husband's treatment and aloofness after the first month of their marriage that ended up with separation just four months into the relationship. Despite her young age, her negative experience and feeling of being used, Nour still demonstrated a sense of agency and responsibility in both her decision to marry soon after arriving to Egypt and her desire to remarry again after the failure of the first attempt. Her justifications reflected deep self-awareness of her social position and she was able to identify the best options and alternative to make the best out of the situation.

D: So he told you he is married and he wanted to marry again in secret?

$\mathrm{N}$ : Yes

D: And what was your impression?

M: That his wife will eventually know by time. Nothing can be hidden

D: Didn't you think, why would I be a second wife? I want to be a first wife?

M: No

D: Why?

M: Because I have special circumstances, I am not a normal girl.

D: Don't you think that this is lowering one's standards?

$\mathrm{N}$ : Dear, it's not us. It's the world around us that forces us (to think and act this way). Even if you are convinced, the society around you won't be convinced.

12 So she would be his lawful wife religiously but socially she still stays with her parents until they prepare for the wedding and the new place. This facilitates his visitation and them getting to know each other. Having sex would be lawful but is socially frowned upon. If they separate, she is considered divorced but there are usually no documents to prove the marriage and divorce. 
D: You are right

$\mathrm{N}$ : Excuse me, I'm sure your study showed you, but most of our society is not like that. Even if you convince yourself.

D: Do you mean that you might be convinced with one thing but the society obliges you to another?

N: Exactly. So why would I bother/pressure myself. If I wanted to marry a single man, no one would want my daughter [...]

D: Oh so you mean you don't care if you are a first or a second wife as long as your daughter is with you?

$\mathrm{N}$ : Yes dear. Excuse me but for women like us we don't think about ourselves, we think about our children. When you buy anything for the house do you think of yourself or your son? [...] In my country, I had my rights and I was able to manage. Here I am in a strange country. Why would I work and humiliate myself, meet this and meet that, the good and the bad? No, I apply Sutra to myself and my daughter and find a human being who is honest and straightforward and offers me a decent life. I'm not saying that I want a car and a big house. Middle ground. A decent life....

For Nour, she knew there are social restrictions that are not just present due to her gender and social status: a widow with a child, but also due to her forced migration status and being in a foreign country. She was convinced that a woman's "natural path is to eventually get married." Her forced migration status, however, have turned this natural path, which might now comprise more limited and slightly different options given her current social status, into a solution, an opportunity, and even, one might argue, an advantage because of her gender. Based on her rationale, other solutions such as working, as a hairdresser, which was her job before she married her first husband, would keep her away from her daughter and expose her to a relatively foreign culture hence making her prone to exploitation and "humiliation" as she described it. For her, marriage was the "safe" or the "decent" option, if not the obvious one in her situation, especially given that her child was her priority. She expressed her dissatisfaction with the idea of Egyptian men seeking a Syrian woman per se and described some of them as "wanting to try the new fruit in the market."

During our conversation, we were both trying to figure out the reason why her ex-husband called the marriage off. She hesitantly confessed that, after a lot of insistence from him and despite the traditions, she agreed to have sex with him once closer to the end of the first month. Soon after, his treatment and attitude started to change which later escalated to the separation. We debated a few theories to try to make sense of the situation. The "trying the new fruit in the market" explanation was obviously the first and the most depressing 
amongst the potential explanations, especially after adding the intercourse factor. His care about his first family and fear from destroying it was also another explanation. A common theme amongst all the potential explanations is that it seemed that Sutra, unlike the coming story, was not a strong enough reason for this marriage to survive. In fact, basing this marriage solely on Sutra created a fragile relationship, despite any noble intentions.

\section{Marwa: "He Gave Me the Choice and I Chose Sutra"}

Like her younger sister, Marwa's husband was killed in the war five years ago and soon after she moved with her parents to Egypt in 2012. Marwa seemed to be more resourceful and demonstrated higher ability to act on her own than her sister, despite having two kids and growing up in the same context. As soon as she arrived in Egypt, she searched for a job and was able to move among, and often fight for, a few decent office jobs that seemed to bring her great satisfaction. She had two experiences with Sutra marriage, one of which was incomplete. In this case, despite her father's refusal, the Egyptian man, who was also motivated by the religious oblation from supporting orphans, promised her a monthly allowance for her kids. Three months in, however, he asked her hand in marriage again, hoping that his commitment over three months would make a good case for him. After being turned down for the second time, he withdrew his commitment and she had to search for a job again. In the second story, she meets her current husband who constantly reminded her and her family that he is doing this for the children. In fact, before they met each other in person, over the phone, he gave Marwa the choice between Sutra (here implying Sutra through marriage) and just financial support by giving a monthly allowance to her children. She picked the first without hesitation. In the excerpt below, Marwa was describing her conflict between agreeing to marry her husband whom she initially refused because of his looks and between what Sutra would bring her and her kids:

D: ... and what were you looking for in a husband? Did you care about love?

M: Yes, I did care, but I cared more about commitment and religious devotion. I cared about Sutra too.

D: What is the meaning of Sutra?

M: In my opinion, Sutra means a man... when you say "that's it!" no one is going to harass me, no one is going to impose themselves on me. That's it! I am with this man and so I can rest mentally. 
D: Do you mean because he is going to be your support and back bone? M: Yes... however up until that moment I wasn't sure how I felt. I was destroyed but at the same time I had the motivation because of my children [...] Of course my dad didn't allow me to come outside and meet him when he came the first time. I stayed inside and then my husband said I just want to see the kids I don't want to see her. I am here for the kids

D: Oh so he was referring to sheltering orphans?

M: Yes, and he didn't request to see me and my dad really appreciated this gesture. He spoke with the children and gave my daughter money, like allowance, and brought them sweets and he didn't see me despite coming from a long distance. And then my father wanted to see him for a second time and of course I saw him that time but at this time I didn't really approve of him.

D: Why? His looks?

M: Yes, he wasn't good looking. Can you believe that? I was concerned about the looks! But now despite all the problems between us I think he has a peaceful face and he has nice hair too. So I started to see his good looks now.

D: After marriage?

M: Yes... slowly through his good treatment and concern about us. Even until now. Yesterday I was asking him about something and he said are the kids comfortable with it or not? I told him: "but I am not comfortable," so he responded: "I married you for the kids."

D: Does that make you happy or upset?

M: Sometimes it makes me happy and sometimes upset depending on the context.

Marwa, unlike her sister, didn't reject the idea of working to support herself and her kids. In fact, she met her husband because she was searching for a job. She has proven resilience and skill in acquiring jobs and expressed deep satisfaction with her "printer, computer and very nice office." However, despite trying it and experiencing the satisfaction resulting from it, when given the option, she still preferred marriage over working. When her current husband's first wife asked her: "didn't you think about me? What would happen to me when my husband marries a second wife." She simply replied: "No, to be honest, I didn't think about you" implying that was already in a much worse situation and needed to take care of her own self first. Marwa, like Nour and Maha, used her agency to assess the situation and her social position within it and 
took the decision that best served her interest, which extended in the three cases to their children's interest.

\section{7 \\ Discussion}

The trajectory of the three marriages, despite the common label of Sutra, had to do a lot with the man/husband's circumstances, understanding and real reasons behind the marriage. In Maha's case, both the husband and the wife were honest with each other about their intentions and need for intimacy. In such case, Sutra had served as a bonus that reinforced a second marriage against a resisting first wife and has potentially worked as a social justification for the husband who was a public figure. In Nour's case, while it is hard to speculate the ex-husband's real intentions, Sutra and the religious oblation was not a strong enough reason for the marriage to survive. The husband's theoretical and moral understanding of Sutra marriage and his attempt to apply it clashed with his "other" social life and probably conflicted, in his mind, with modernist social dictates of the nuclear monogamous family. In Marwa's case, on the other hand, Sutra was the glue that kept the marriage together thus far. The husband's clear vision of marrying her for the sake of her orphaned children played a major role in giving both the husband and the wife a reason to keep going, despite all the problems as Marwa clarified. It was even a reason for Marwa to fall in love with her husband later on in the marriage and for him to hold on to this marriage despite his first wife's constant call to get a divorce.

The above stories point to the major role the husband and his understanding (or misunderstanding) of Sutra marriage play in determining the success of the marriage. That said, the women on the other hand demonstrated substantial control in making and calculating the initial decision to get married. That is to say, for the three women, the decision to marry using the rationale of Sutra had its mitigating social pressures, some stemming from patriarchy and others stemming from the uprootedness and their forced migration status. I argue here that they all point to the fact that those mitigated social structures particularly gender and refugeeness can offer the refugee women an advantage and an ability to manoeuvre traditions to serve their best interest. In other words, facilitated but not entirely determined by the religious Sutra rhetoric, their labeled "vulnerable" and "victim" status created by social factors, namely, their refugeeness, gender, ethnicity: Syrians (compared to other sub-Saharan refugees such as Sudanese, Eritreans and Somalis), and social position as widows/divorced-with orphaned children had provided them with an opportunity and a solution that are not usually available to other displaced demographics 
in the same context. This statement complicates notions such as agency, victimhood, vulnerability and exploitation to both the contemporary liberal feminist and humanitarian discourses and to the justifications on which many of the Sutra marriage fatwas are built.

\subsection{Liberal Agency and Moral Agency}

Agency in liberal feminist literature and imagination is understood ultimately as the resistance to forms of domination and the capacity to realize one's own interestagainst custom (Mahmood 2001). What I sought to demonstrate through my respondents' narratives is that while a deeper look into those women's testimonies reveals a strong resemblance to the above definition, especially regarding the pursuit of one's interest, this notion of liberal agency captures only a thin layer of those women's experiences. In other words, restricting ourselves to such definition of agency sharply limits our understanding of those women's subjectivities and experiences that were formed by and within non-Western liberal cultural contexts.

The three cases above reveal that the women were still able to utilize relational autonomy ${ }^{13}$ and agency-in its liberal sense, to pursue their interest. A major fracture to this rhetoric, however, is that those women still prescribed themselves to the traditional marriage institution and many other "patriarchal" discourses. That was manifested in Maha's statement: "a woman without a man is like a tree without leaves"; Nour's conviction that the woman's ultimate path is to get married; or Marwa's decision to choose marriage over monthly financial support when given the choice by her future husband. Here, the poststructuralist Foucauldian concept of Subjectification that was later taken by Judith Butler in her gender analysis, is particularly helpful. Subjectification draws attention to power (and norms in Butler's analysis) as both subordinating or constraining and enabling. In other words, the modes that allow and create agency are in fact the products of power operations (they didn't exist before the dominance of this power). Personal preferences and gender roles are social constructs dictated to a large extent by culture, upbringing and other social forces. For instance, Nour's conviction that marriage is the natural path to any woman has helped form her options and preferences and shaped her understanding of marriage as "the decent" option for her situation. It has also

13 Relational autonomy is the label that has been given to an alternative conception of what it means to be "a free, self-governing agent who is also socially constituted and who possibly defines her basic value commitments in terms of inter- personal relations and mutual dependencies" (Christman 2004, 143). Recognizing relational autonomy as an analytical tool helps us see those women as aware of their social position, aware of the social transaction or the mutual benefit created by this form of marriage. 
helped set her priorities when it came to her obligations to her daughter as well as her understanding of love and intimacy.

This is not to deny the patriarchal and unjust conditions, such as fear from harassment or distress about personal safety, that underlie those women's socio-cultural milieu and shape their preferences and decision to marry. Rather, I want to pick up on Saba Mahmood's argument which sought to problematize a question that has dominated scholarship, such as: "how do women contribute to reproducing their own domination, and how do they resist or subvert it?" (Mahmood 2001, 255). Here, I would like to recall the anti-colonial critique that challenges the assumption that the desire to freedom from subordination is universal and innate to human nature (ibid., 256). I argue that the decision/ desire to marry for those women is determined by a complex web shaped by: (a) explicit/liberal understanding of agency and weighing one's interest against custom; (b) societal patriarchal dictations that re-articulate marriage as the decent and almost the only solution; and (c) those women's moral agency. Such moral agency does not particularly aim to enhance one's material interest or status but rather to "attain a certain kind of state of happiness, purity, wisdom, perfection, or immortality" (ibid., 210). In short, those women have perceived marriage as an agentive act not just in terms of promoting their socio-economic interest or to manoeuvre social structure but also as a moral and virtuous act that complements their existence and understanding of their femininity and gender-which, recalling Butler (1990), should not be understood as having an inner core or a value independent from the social.

\subsection{Marriage, Intimacy and the Nuclear Family}

Another conceptual challenge that the narratives of those women have imposed on liberal scholarship is the reconceptualization of the notion of marriage. While not challenging the idea of marriage as an institution per se, many of the women have posed important challenges to some of the core principles of marriage as understood in a postmodern world. At first glance, and consistent with the point made above about the multi-layered understanding and embodiment of agency, one could identify some pragmatic motives behind such challenges such as preferring and pursuing a polygamous marriage for reasons such as wanting to be only part-time wives which gives them more time for their children. Some others have also refused to register the marriage officially and limited it to a customary contract for some calculated reasons such as simplifying any potential separation especially in the event that they wanted to leave the country. However, beyond those pragmatic motives and throughout the narratives, one is able to trace malleable meanings of intimacy, romantic love and the nuclear family which pose challenges to the simplistic 
explanations of gender inequality in non-Western, particularly in this case Islamic, cultures.

For instance, despite her negative experience, Nour was actually pleased with her ex-husband's interest in applying Sutra to a widow and her orphaned children. As a researcher, I was astonished by the fact that she would be happy that someone is marrying her out of apparent charity. She clarified that she appreciated his honesty and noble intention and she was convinced that love, an important factor still, is a gradual process that will come later. When I reflected back on my astonishment, I could trace in my rationale elements of a colonized understanding of intimate relations that are often explained through convictions about the nuclear family as well as individualized perceptions, commercialized romantic expressions and monopolized affections. This malleable understanding of marriage and gender identity should not be understood merely in terms of strategic malleability, but that it also "emerges because of her traditionally ascribed gender identity not despite of it" (Taha 2017, 117).

\subsection{Reimagining Contemporary Jurisprudence}

So far, I have spent time arguing for reimagining the meanings of agency, family and marriage to understand the cultural complexity of those women's consciousness and articulation of autonomy, intimacy and gender roles. Now I want to direct the attention to how the above accounts and analysis are helpful to contemporary Islamic jurisprudence, particularly in two main ways. First, as was evident in the previous section, it destabilizes the orientalised portrayal of Third World refugee women, particularly Muslim refugee women, as passive victims of a primitive patriarchal legal system, here namely figh. ${ }^{14}$ Rather, the women's accounts show how social restrictions and structures that produce vulnerability due to gender and forced migration have simultaneously opened new spaces and opportunities to, and have been utilized by, this social group. Moreover, the accounts offer refugee researchers tools to explore new areas and new meanings for notions such as shelter and resettlement. Thus, while the latter might not necessarily be used in explaining the rational of a religious verdict, it still provides the jurists and Islamic scholars with a common "language" with feminist and human rights advocates to engage in a meaningful debate on gender dynamics, gender rights and gender-based violence in Muslim societies.

That said, as a postcolonial feminist myself, my objective from this paper is not by any means to deny forces of social oppression to women in Islamic, as

14 Almost always confused with and is known as sharia in the West. 
well as other, cultures. There is some extensive work by specialized ethicists who identify areas of moral and ethical dilemmas surrounding Sutra marriage, particularly from the male-perspective and as a product of patriarchal forces (see for instance, Al-Khatib 2018). Rather, a second benefit from revisiting notions such as agency, marriage and victimhood from a critical sociological perspective to contemporary Islamic Jurisprudence is to offer jurists a deeper sociological understanding of the realities of women and particularly refugee women in Muslim societies. Recalling Ramadan's argument about the imperative of mastering the field of knowledge for which a fatwa is being developed, the process known as Ijtihâd, or "when legal scholars working in the field of social affairs produce an informed opinion (fatwa) on a given subject where the texts are either open to interpretation or silent" that is both scripturally and ethically informed (Ramadan 2017, 14), should particularly benefit from such analysis. Hence, I would like to conclude by highlighting a few sociological insights that are relevant to this case study:

- Understanding the larger forces and explanations that pushed the refugee women to marry in the first place. Refugee women have been often portrayed in sociological and anthropological studies as weak victims of war and violence and "thus in great need of protection from male family members or from foreign humanitarian aid workers" (Young and Chan 2015). It is important to recognize that accepting this perception uncritically would lead to consolidating oppressive and marginalizing forces that continue to determine the experiences and the social position of women in Muslim countries in general and Muslim refugee women in particular (Hajdukowski-Ahmed, Khanlou, \& Moussa, 2008). That said, it is also important to recognize the patriarchal elements that shaped those women's understanding of Sutra. For instance, the three women agreed that marriage offers them a shield against sexual harassment. Harassment could be due to their gender, uprootedness, or both. Thus, while Sutra marriage can be argued as a practical, "decent" and culturally relevant solution to many refugee women who are also single mothers, it cannot be viewed in isolation from other unjust conditions, such as fear from harassment or personal safety, that shape those women's decision to marry. Moreover, Mutaz al-Khatib, addresses some ethical issues surrounding the patriarchal interpretations of Sutra marriage in Muslimmajority societies that fail to engage meaningfully with issues surrounding conflict of interest, subliminal levels of exploitation and coercion, and limiting the purpose of marriage to pure lust and physical needs (al-Khatib 2018). Understanding the double precarity of those women should contribute to a better assessment in weighing the benefits (manfa'a) and harm (darar) of marrying refugee women. Which brings us to the next point. 
- Emphasizing knowledge about trauma, mental health and the double precarity status of many refugee women. Many, if not most refugees, whether men, women or children, experience traumatic events such as injury, destroying of neighbourhood, residence and personal belongings, torture and persecution, inhumane living conditions, witnessing the death of others and close ones (Porter \& Haslam 2005). For women refugees, gender-based violence (G BV) is a particular threat. The latter is not just limited to physical and sexual violence but includes psychological and emotional abuse as well (Young and Chan 2015). As a result, many refugee women suffer from mental health symptoms such as depression, anxiety, and posttraumatic stress disorder (Guruge et al. 20o9; Young and Chan 2015). Putting that in mind, one cannot rule out the idea that despite suffering from an abusive relationship, or even just an unhappy marriage due to factors such as incompatibility, marrying based on what is available, romantic void or feeling of unfairness due to a first marriage or the secrecy of marriage, some refugee women will still choose or feel obliged to stay in that marriage (Ho and Pavlish 2011). Hence, it is important when issuing fatwas like fatwa (1) discussed above, to put notions such as trauma and double precarity into account when considering the best interest of the refugee women. Double precarity is the product of two elements: the woman's gendered uprootedness and the more than likely loss of her family and social support, as well as precarity resulting from the marriage itself. Many such marriages are often hidden from a first wife and even public spheres and in many cases, is not registered i.e. customary or 'urfi marriage. The previous two criteria were present, at least at some point, in Maha, Nour and Marwa's stories. While Maha and Marwa didn't suffer major consequences from the precarious status of their marriages, other than complaints about not seeing their husbands enough, in Nour's case, it didn't make it any harder on her exhusband to "try the new fruit in the market" and to eventually walk away leaving her emotionally violated. In Nour's story, however, the secrecy and the precarious status of the marriage extended the harm to the husband and his first family when Nour, who was full of vengeance and arguably still suffering from war trauma, eventually called the first wife and informed her about her husband's "betrayal." This puts us against the inevitable question of how much protection does protection marriage or Sutra marriage really offer to a refugee woman?

- Recognizing the blurry line between the man's personal interest and his striving for religious oblation. Recalling the issues discussed above regarding conflict of interest and subliminal levels of exploitation, the case of Nour demonstrates that the intention of Sutra is not always enough to secure 
a "healing" solution to the refugee woman. In fact, more damage can be caused if the fatwa does not tackle the complex factors that inform the decision-making process of many men and women in current Muslim societies who are also highly influenced by modernity. ${ }^{15}$ Here, I am more accurately referring to the Muslim world's shock as a repercussion of "European" modernity. Such shock has made the Muslim cultures' absorption of modernity to be "extremely complicated and problematic" (Tagharobi and Zarei 2015). One of the repercussions of modernity in some Muslim societies, particular to our Egyptian case study, is the idea of the nuclear family or the monogamous marriage that gathers a man, a woman and their decedents. The point of dragging monogamy and polygamy to this conversation is not meant to assess its rationale and ethics under contemporary conditions. Rather, this paper, as emphasized throughout, is meant to offer a deeper sociological understanding of the realities and the forces dictating contemporary Muslim societies for which fatwas are issued. A jurist's grasp of the implications of modernity and its impact on the emergence of a new sense of self amongst Muslim men and women should thus be factored in when assessing the modern world's social, particularly gendered, issues. More importantly, such implications should be considered in understanding and (re)defining the "ethical" and the relationship between the legal and the ethical in Islamic philosophy and jurisprudence.

\section{Conclusion}

Marriage as a tool to mitigate insecurity and precarity is not a novel practice to Syrian women, with Bosnians and Iraqis before them. Studies on Tsunami survivors (Hyndman 2007) and North-Korean female border crossers to China (Kim 2014), elaborate interesting aspects of marriage as a survival tool for forced migrants and migrants with a precarious status. Still, marriage between Arab men and Syrian refugee women was proven to be a problematic issue that has drawn a strong media and advocacy attention over the past few years. Often described as exploitation due to the precarious status of many of the women especially those in refugee camps, these marriages were labelled and compared to forced marriages, sex trafficking and child marriage.

15 While it is hard to define, the term "modernity" was coined to capture the changes occurring in Europe due to industrialization, urbanization and democratization. One major change is a revolution in the human experience due to "the development of a new sense of self, of subjectivity and individuality. This idea distinguishes the modern individual from the traditional one" (Haferkamp, and Smelser 1992). 
This paper does not aim to understate gender-based violence and oppression to women all across the globe, Muslim cultures included. Nor is it concerned with passing moral judgements or ethical evaluation to the phenomenon and some of its repercussions, such as polygamy and the often-opaque marital rights. It should be noted here, however, that the jurisprudential culture and its ethical theories are not constant, nor do they spring from a void (Ramadan 2017, 8). As Ramadan puts it:

the historical circumstances and internal debates within Muslim communities should not be overlooked. Relationships between political power, religious institutions, as well as internal conflicts between schools of thought and jurisprudence all had an impact on the way moral values were understood, organized and applied (ibid., 8).

Hence, the objective of this paper was concerned with identifying and dissecting social structures, hegemonic discourses and power relations that explain and shape both: gendered phenomena such as Sutra marriage as well as this jurisprudential culture in order to better inform the contemporary ethics of migration debates in a way that is inclusive and decolonized.

Along those lines, this paper is also a call to reflect on how the jurisprudential culture that influences the ijtihād process and sets the parameter for Islamic ethical theories often mirror hegemonic discourses and reinforce dynamics of social injustice. Thus, an equally important question that was left out of this paper is the dilemma of the-more-than-possible politicization of such moral parameters and the Islamic science of ethics. How could, for instance, nationalistic ideologies motivate the connection between certain legal norms and particular understandings of ethical principles? Marion Holms

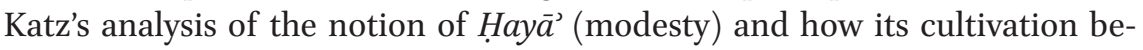
came "a central trope of legal discussions of veiling in the modern period" is a case in point (Katz 2015, 26). While her argument was meant to clarify the evolution of the relationship between jurisprudence and ethics in Islamic sciences, her analysis draws attention to the problematic of how ethical parameters and moral theories can be utilized to reinforce political ideologies.

In addition, a concurrent objective of this case study is to contribute to the body of literature that aims to resist the misrepresented, simplistic and orientalised narratives that portray Muslim women, and refugee women in particular, as the passive victims and the Arab man as the oppressive pariah (see for instance, Alhayek 2014). I have utilized an anti-colonial lens to offer a deeper reading to the case of Sutra marriage in Egypt. While not without tension, I propose that using an anti-colonial language when assessing the phenomenon offers two benefits. First, it offers a critical language and a communication tool to respond to accusations from contemporary international humanitarian, 
refugee rights and feminist discourses and conceptions. Such conceptions often stigmatize similar conjugal arrangements under notions such as exploitation, sex trafficking and forced marriage. An anticolonial framework challenges the foundations of such rhetoric by questioning, as was argued above, the understanding of notions such as agency and victimhood.

Second, an anti-colonial feminist lens proposes a gendered approach to jurisprudence that is more in touch with the reality of marginalized groups. While one of the objectives of the paper was to demonstrate the difference between vulnerability and victimhood and the fact that the refugee woman may enjoy a substantial level of "relational autonomy" in the initial decision of getting married, relying solely on religious oblation and the man's "pure" intention from the marriage can be problematic to the trajectory or the end result of the marriage. A gendered approach to the fatwa then, should reinforce the role of the jurist beyond merely concluding the legal verdict to embracing a vision of "ethico-religious obligations" and include principles such as Ulfa (friendship, affection, and intimacy) (Katz 2015) to guide and rectify the society's intellectual and moral assessments of when and how to apply (or not to apply) Sutra marriage to refugee, as well as other, women. Moreover, the fatwa should offer provisions that effectively allow those women to exercise their marital rights. Recognition of patriarchal social forces, trauma and precarity, the exaggerated power in the hands of the man due to the double precarity of those refugee women along with the modernity shock are some elements that facilitate and inform this end.

\section{Acknowledgements}

This work would not have been possible without the funding of the Humanitarian Response Network of Canada (HRN) and the Logistical support of Syria Al Gad Relief Foundation that facilitated the interview appointments and location with the respondents. I would also like to thank the Center for Refugee Studies at York University and my supervisory committee, Professor Christopher Kyriakides, Professor Katherine Bischoping and Professor Jennifer Hyndman for their tireless commitment and support to my work. 


\section{Bibliography}

AlHamoud, Ibrahim Bin Nasir. (2011). Huqooq al-Arāmīl wa al-Mutalaqāt (the rights of widows and divorcées). Islam Today, November 6.

Alhayek, Katty. (2014). Double Marginalization: The Invisibility of Syrian Refugee Women's Perspectives in Mainstream Online Activism and Global Media."Feminist Media Studies, 14(4): 696-700.

Al-Khatib, Mutaz. (2018). Zawjat al-Shahīd wa al-Zawāj ghayr al-Akhlāqī (the wife of the martyr and the immoral marriage). Al-Jazeera blogs, January 11. <https://blogs.

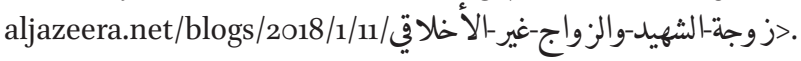

Barkan, L. (2012). Criticism in Arab World Over Exploitation of Syrian Refugee Girls For Purposes Of Marriage. The Middle East Media Research Institute, November 12. Accessed May 25, 2018. <https://www.memri.org/reports/criticism-arab-world-overexploitation-syrian-refugee-girls-purposes-marriage $>$.

Butler, Judith. (1990). Gender Trouble, Feminist Theory, and Psychoanalytic Discourse. In Feminism/Postmodernism, edited by Linda Nicholson, 324-340. New York: Routledge.

Castles, Stephen. (2002). Migration and Community Formation under Conditions of Globalization. International Migration Review, 36(4): 1143-1168.

Christman, John. (2004). Relational Autonomy, Liberal Individualism, and the Social Constitution of Selves. Philosophical Studies, 117(1): 143-164.

Dei, Geirge Sefa. (2012). Indigenous anti-colonial knowledge as "heritage knowledge" for promoting Black/African education in diasporic contexts. Decolonization: Indigeneity, Education \& Society, 1(1): 102-119.

EсHо Factsheet-Egypt (2018), By European Commission's Directorate-General for European Civil Protection and Humanitarian Aid Operations, available at: <https:// reliefweb.int/report/egypt/echo-factsheet-egypt-january-2018>.

Geha, Rani. (2012). Syrian Refugees Struggle in Egypt. Al-Monitor, November 21. Availableat:<http://www.al-monitor.com/pulse/iw/politics/2012/11/the-plight-of-syrianrefugees-in-egypt.html>.

Guruge, Sepali, and Janice Humphreys. (2009). Barriers that affect abused immigrant women's access to and use of formal social supports. Canadian Journal of Nursing Research, 41(3): 64-84.

Haferkamp, Hans, and Neil J. Smelser, eds. (1992). Social Change and Modernity. Berkeley: University of California press. Available at: <http://publishing.cdlib.org/ ucpressebooks/view?docId=ft6oooo78s\&chunk.id=doe1681 $>$.

Hajdukowski-Ahmed, Maroussia, Nazilla Khanlou and Helene Moussa. (2008). Not Born a Refugee Woman: Contesting identities, rethinking practices. NY, UsA: Berghahn Books. 
Hassan, Khalid. (2015). Why Some Syrian Refugees See Marriage as the Only Option. Al-Monitor, December 8. Available at: <http://www.al-monitor.com/pulse/originals/ 2015/12/egypt-syria-refugees-women-marriage-aid.html\#ixzz4LTGBszPg>.

Ho, Anita, and Carol Pavlish. (2011). Indivisibility of accountability and empowerment in tackling gender-based violence: Lessons from a refugee camp in Rwanda.Journal of Refugee Studies 24(1): 88-109.

Hyndman, Jennifer. (2007). The Securitization of Fear in Post-Tsunami Sri Lanka." Annals of the Association of American Geographers, 97(2): 361-372.

Katz, Marion Holmes. (2015). Ethics, Gender, and the Islamic Legal Project. The Abdallah S. Kamel Lecture Series on Islamic Law and Civilization. New Haven, Connecticut: Yale Law School.

Kim, Sung Kyung. (2014). "I am well-cooked food": survival strategies of North Korean female border-crossers and possibilities for empowerment. Inter-Asia Cultural Studies 15(4): 553-571.

Mahmood, Saba. (2001). Feminist theory, embodiment, and the docile agent: Some reflections on the Egyptian Islamic revival. Cultural Anthropology 16(2): 202-236.

Mir-Hosseini, Ziba. (2003). The construction of gender in Islamic legal thought and strategies for reform. Hawwa 1(1): 1-28.

Mohanty, Chandra Talpadi. (1984). Under Western eyes: Feminist scholarship and colonial discourses. Boundary 2(12/13): 333-358.

Natour, Rajaa. (2016). Neither Marriage Nor Protection for Syrian Women. Linkedin, February 27. Available at: <https://www.linkedin.com/pulse/neither-marriage-norprotection-syrian-women-rajaa-natoure $>$.

Palestine Refugees: Locations and Numbers (2010), by IRIN. Available at: <http:// www.irinnews.org/report/89571/middle-east-palestinian-refugee-numberswhere abouts >.

Porter, Matthew, and Nick Haslam. (2005). Predisplacement and postdisplacement factors associated with mental health of refugees and internally displaced persons: a meta-analysis. Jama, 294(5):602-612.

Ramadan, Tariq. (2017). Islamic Ethics: Sources, Methodology and Application. In Islamic Bioethics: Current Issues and Challenges, edited by Alireza Bagheri and Khalid Alali. Series of Intercultural Dialogue in Bioethics, vol. 2:1-21.

Sachedina, Abdulaziz. (1999). Woman, Half-the-Man? Crisis in Male Epistemology in Islamic Jurisprudence. In Perspectives on Islamic Law, Justice and Society, edited by R.S. Khare. New York, Rowman \& Littlefield.

Spivak, Gayatry. (1988). Can the subaltern Speak. In Can the Subaltern Speak?: Reflections on the History of an Idea, edited by Rosalind C. Morris. Columbia, Columbia University Press, 21-78.

Tagharobi, Kaveh, and Ali Zarei. (2015). Accommodating an Unexpected Guest. The Modernist World, 439 . 
Young, Marta Y., and K. Jacky Chan. (2015). The Psychological Experience of Refugees: A Gender and Cultural Analysis. In Safdar, Saba, and Natasza Kosakowska-Berezecka. "Psychology of Gender Through the Lens of Culture: Theories and Applications. Springer International Publishing, 17-36. 